\title{
FAKTOR - FAKTOR YANG MEMPENGARUHI PENYERAPAN TENAGA KERJA INDUSTRI MANUFAKTUR BESAR DAN MENENGAH PADA TINGKAT KABUPATEN / KOTA DI JAWA TIMUR
}

\author{
Oleh: \\ Kholidah Azhar \\ Zainal Arifin \\ Alumni Fakultas Ekonomi Universitas Muhammadiyah Malang \\ E-mail/No. Hp: idah_az@gmail.com/-
}

\begin{abstract}
This research tries to know factor that regard industrial labour absorption manufacturing outgrows and intermediate on regency / city at Javanese East. With insert free variable total industrial pay, industrial raw material, total manufacturing industrial enterprise and manufacturing industry production is gotten usufructs that variable fourth that free signifikan's ala having for to labouring absorption on industrial manufacturing with determinant coefficient $R^{2}$ as big as $94,8 \%$ on zoom glosses over $5 \%$.
\end{abstract}

Keywords: manufacturing industry, labouring absorption, and East Java

\begin{abstract}
Abstrak
Penelitian ini berusaha untuk mengetahui faktor-faktor yang mempengaruhi penyerapan tenaga kerja industri manufaktur besar dan menengah pada kabupaten/kota di Jawa Timur. Dengan memasukkan variabel bebas total upah industri, bahan baku industri, jumlah perusahaan industri manufaktur dan produksi industri manufaktur diperoleh hasil bahwa keempat variabel bebas tersebut secara signifikan berpengaruh terhadap penyerapan tenaga kerja pada industri manufaktur dengan koefisien determinasi $R^{2}$ sebesar $94,8 \%$ pada tingkat kesalahan $5 \%$.
\end{abstract}

Kata Kunci: industri manufaktur, penyerapan tenaga kerja, dan Jawa Timur

\section{PENDAHULUAN}

Sektor industri yang dipandang strategis adalah industri manufaktur. Industri manufaktur dipandang sebagai pendorong atau penggerak perekonomian daerah. Seperti umumna negara sedang berkembang, Indonesia memiliki sumberdaya alam yang melimpah dan setiap daerah memiliki keragaman keunggulan sumberdaya alam. Di sisi lain Indonesia memiliki jumlah penduduk atau angkatan kerja yang sangat tinggi. Sektor manufaktur menjadi media untuk memanfaatkan sumberdaya alam yang melimpah, yang pada gilirannya akan mampu menyerap tenaga kerja yang besar. (Jurnal Ekonomi Pembangunan, http// www.google.com) 
Era globalisasi ekonomi yang disertai dengan pesatnya perkembangan teknologi, berdampak sangat ketatnya persaingan, dan cepatnya terjadi perubahan lingkungan usaha. Produk-produk hasil manufaktur di dalam negeri saat ini begitu keluar dari pabrik langsung berkompetisi dengan produk luar negeri, dan dunia usaha pun harus menerima kenyataan bahwa pesatnya perkembangan teknologi telah mengakibatkan cepat usangnya fasilitas produksi, semakin singkatnya masa edar produk, serta semakin rendahnya margin keuntungan. Dalam melaksanakan proses pembangunan industri, keadaan tersebut merupakan kenyataan yang harus dihadapi serta harus menjadi pertimbangan yang menentukan dalam setiap kebijakan yang akan dikeluarkan, dan sekaligus merupakan paradigma baru yang harus dihadapi oleh negara manapun dalam melaksanakan proses industrialisasi negaranya. Atas dasar pemikiran tersebut kebijakan dalam pembangunan industri Indonesia harus dapat menjawab tantangan globalisasi ekonomi dunia dan mampu mengantisipasi perkembangan perubahan lingkungan yang cepat. Persaingan internasional merupakan suatu perspektif baru bagi semua negara, sehingga fokus strategi pembangunan industri di masa depan adalah membangun daya saing sektor industri yang berkelanjutan di pasar domestik dan internasional. (http//www.scibd.com).

Dalam kurun waktu 1996-2006 jumlah industri berskala sedang dan besar cenderung terus meningkat. Jumlah perusahaan pada industri manufaktur secara keseluruhan sempat mengalami penurunan dalam masa krisis 1997/ 1998, namun setelahnya secara bertahap cenderung meningkat kembali. Dilihat dari skala usaha, sekitar $70 \%$ dari perusahaan yang ada tersebut termasuk dalam kategori industri sedang. Selain itu, sejak tahun 2004 rasio perusahaan industri berskala besar terhadap keseluruhan jumlah industri juga terus menurun, sejalan dengan semakin meningkatnya rasio industri sedang. Bila dilihat dari komposisinya, Industri Makanan dan Minuman, Tekstil, Pakaian Jadi, dan Furnitur mendominasi jumlah perusahaan dalam industri. Lebih dari $50 \%$ dari industri besar dan 
sedang adalah industri yang bergerak di empat golongan industri tersebut.

Dilihat dari jumlah tenaga kerja yang dapat diserap, peran sektor industri manufaktur dalam menyerap tenaga kerja nasional memang masih relatif rendah. Distribusi penyerapan tenaga kerja masih terkonsentrasi pada sektor pertanian (41\%) dan sektor jasa seperti perdagangan (21\%), pengangkutan $(6 \%)$ dan jasa- jasa lain $(12 \%)$. Sementara itu, pangsa sektor industri manufaktur cenderung stagnan, dan bahkan cenderung berada dalam tren menurun. Apabila dilihat dari jenis industrinya, Industri Pakaian Jadi, Tekstil, Makanan dan Minuman, serta Furnitur merupakan industri yang menyerap tenaga kerja terbesar. Hal ini sejalan dengan perkembangan jumlah perusahaan dalam industri tersebut.

Apabila dilihat dari nilai output yang dihasilkan oleh keseluruhan industri manufaktur yang berskala besar dan sedang, secara umum terlihat kinerja industri pascakrisis masih di bawah prakrisis. Rata-rata pertumbuhan output pada periode prakrisis (1991-1995) mencapai sekitar $22 \%$, sementara pada periode pascakrisis (2002 - 2006) baru mencapai sekitar 12\%. Dilihat dari pangsa terhadap keseluruhan nilai produksi, penyumbang terbesar nilai output adalah industri makanan dan minuman,tekstil, kimia, logam, karet dan barang plastik, serta industri kendaraan roda empat. Apabila dilihat dari sisi nilai tambah, gambaran yang diperoleh hampir serupa dengan perkembangan nilai output, dimana pertumbuhan nilai tambah periode pascakrisis masih lebih rendah dari pertumbuhan prakrisis (dari indikator industri besar dan sedang terbitan BPS). Adapun yang dimaksud nilai tambah adalah besarnya output dikurangi biaya input atau biaya antara. Dilihat dari jenis industrinya, penyumbang terbesar dalam nilai tambah adalah industri makanan dan minuman, tembakau, tekstil, kertas, dan industri bahan kimia. (http//jatim.bps.go.id).

Sektor industri Manufaktur mampu menyerap tenaga kerja dengan kontribusi dari total tenaga kerja yang bekerja di Jawa Timur sebesar $22,32 \%$, namun penyerapan tenaga kerja masih di bawah sektor pertanian. Hal ini disebabkan karena pada umumnya untuk dapat bekerja pada sektor Industri masih 
memerlukan persyaratan tertentu,

Dalam era globalisasi upayayang salah satunya adalah upaya dalam pengembangan daerah pendidikan.

Jawa Timur merupakan salah satu propinsi dengan industri terbesar setelah Jakarta. Dengan infra struktur yang sangat menunjang bagi pertumbuhan industri baik industri kecil, menengah maupun besar. Jawa Timur juga merupakan salah satu propinsi yang terpadat penduduknya di Indonesia. Berdasarkan sensus penduduk (tahun 2000) penduduk Jawa Timur adalah 34.899.236 jiwa dengan pertumbuhan rata-rata setiap tahunnya mencapai $1,08 \%$. Dengan kepadatan penduduk $720 \mathrm{jiwa} / \mathrm{km} 2$ dengan penyebaran penduduk tidak merata. (http//jatim.bps.go.id).

Dari jumlah penduduk yang bekerja pada tahun 2000, sebagian besar tertampung di sektor pertanian (46,18\%), di sektor industri $(22,32 \%)$, perdagangan $(18,80 \%)$ dan sektor jasa $(12,75 \%)$. Menurut Dinas Tenaga Kerja, angkatan kerja yang pada tahun 1999 tercatat sebanyak 17.554,632 orang, pada tahun 2000 meningkat menjadi 18.920 .000 orang. Sementara itu kesempatan kerja yang tersedia adalah 17.960.400 orang. saat ini sangat gencar dilakukan. Pertumbuhan ekonomi suatu provinsi maupun negara akan berhasil bila perekonomian daerah tumbuh. Suatu negara tak akan berkembang kecuali daerah-daerahnya berkembang. Demikian pula dengan pola distribusi industri yang tidak merata antara daerah yang satu dengan lainnya mengakibatkan juga pada pola penyerapan tenaga kerja industri yang timpang antara daerah satu dengan daerah yang lainnya.

Total penyerapan tenaga kerja industri manufaktur besar dan menengah di Jawa Timur pada tahun 2002 sebanyak 845.994 tenaga kerja, sedangkan tahun 2003 mengalami penurunan menjadi 836.073 tenaga kerja. Tahun 2004, 2005, 2006, 2007 dan 2008 mengalami kenaikan kembali sebersar 797.037 tenaga kerja, 804.945 tenaga kerja, 813.954 tenaga kerja, 856.534 tenaga kerja dan 881.532 tenaga kerja.

Berdasarkan dari uraian di atas diketahui bahwa sektor industri manufaktur mempunyai kemampuan menyerap tenaga kerja yang tinggi dengan pola distribusi yang tidak 
merata di tiap-tiap daerah serta mengalami fluktuasi sehingga peneliti mengambil judul "Faktor - Faktor yang Mempengaruhi Peyerapan Tenaga Kerja Industri Manufaktur Besar dan Menengah pada Tingkat Kabupaten / Kota di Jawa Timur".

\section{METODE PENELITIAN}

Lokasi pada penelitian ini adalah seluruh Kabupaten/ Kota di Pronvinsi Jawa Timur. Terdapat 29 Kapubaten yang meliputi : Pacitan, Ponorogo,

Trenggalek,Tulungagung,Blitar, Kediri, Malang, Lumajang, Jember, Banyuwangi, Bondowoso, Situbondo, Probolinggo, Pasuruan, Sidoarjo, Mojokerto, jombang, Nganjuk, Madiun, Magetan, Ngawi, Bojonegoro, Tuban, Lamongan, Gresik, Bangkalan, Sampang, Pamekasan, Sumenep. Dan 9 Kota yang meliputi : Kediri, Blitar, Malang, Probolinggo, Pasuruan, Mojokerto, Madiun, Surabaya, Batu.

Penelitian ini merupakan penelitian deskriptif kuantitatif yang sifatnya memberikan gambaran secara umum bahasan yang diteliti dalam data atau angka yang kemudia dianalisa, diklasifikasikan dan dipresentasikan dalam bentuk uraian. Adapun variabel terikat penelitian ini adalah penyerapan tenaga kerja pada industri manufaktur besar dan menengah pada tingkat kabupaten/ kota di Jawa Timur. Sedangkan variabel bebasnya adalah total upah, bahan baku, jumlah perusahaan, dan produksi.

Pada penelitian ini peneliti menggunakan data panel. Keuntungan data panel adalah: pertama, biasanya menyediakan jumlah observasi yang lebih banyak sehingga meningkatkan degree of freedom. Keuntungan kedua, karena pendekatan data panel memungkinkan peneliti untuk menganalisis pernyataan - pernyataan ekonomi yang tidak dapat diselesaikan dengan data croos section atau pun time series. Oleh karena data croos section diyakini menunjukkan perilaku jangka panjang sementara dan time series menunjukkan jangka pendek, maka kombinasinya dalam data panel memungkinkan perumusan srtuktur dinamis yang komprehensif.

Maka dalam penelitian ini akan digunakan pendekatan data panel dalam upaya mengestimasi model yang ada. Teknik yang dipakai OLS 
(Ordinary Least Square). Adapun spesifikasi model panel dalam bentuk log yang akan diestimasi dalam penelitian ini adalah :

$\log Y=\log \beta_{0}+\log \beta_{1} X_{1}+\log \beta_{2}$ $X_{2}+\log \beta_{3} X_{3}+\log \beta_{4} X_{4}+e$

Dimana: $\mathrm{Y}=$ Penyerapan Tenaga kerja industri manufaktur besar dan menengah pada tingkat kabupaten/ kota di Jawa Timur; X1 = Total Upah industri manufaktur besar dan menengah pada tingkat kabupaten/ kota di Jawa Timur; $\mathrm{X}_{2}=$ Bahan Baku industri manufaktur besar dan menengah pada tingkat kabupaten/ kota di Jawa Timur; $\mathrm{X}_{3}=$ Jumlah Perusahaan industri manufaktur besar dan menengah pada tingkat kabupaten/ kota di Jawa Timur; $\mathrm{X}_{4}=$ Produksi industri manufaktur besar dan menengah pada tingkat kabupaten/ kota di Jawa Timur.

Adapun untuk mengetahui klasifikasi daerah menurut empat kriteria meliputi: keadaan sangat tinggi, tinggi, sedang dan rendah adalah dengan cara menghitung besarnya nilai rata-rata (mean) dan standart deviasi untuk tiap-tiap variabel yakni penyerapan tenaga kerja,total upah, bahan baku, jumlah perusahaan dan produksi industri manufaktur besar dan menengah pada tingkat kabupaten/kota tahun 20022008. Adapun pengelompokkan empat klasifikasi adalah kriteria sangat tinggi diperoleh dari hasil perhitungan diatas nilai mean + standart deviasi; kriteria tinggi diperoleh dari hasil perhitungan mean sampai pada nilai mean+ standart deviasi; kriteria sedang diperoleh dari hasil perhitungan mean sampai pada nilai mean - standart deviasi; dan kriteria rendah diperoleh dari hasil perhitungan dibawah nilai mean standart deviasi.

\section{PEMBAHASAN}

Industri manufaktur besar dan menengah pada tingkat kabupaten/ kota di Jawa Timur tahun 2002 2008 menunjukkan bahwa penyerapan tenaga kerja tertinggi yaitu Kabupaten Sidoarjo 18,33\% atau total sebesar 1.105.759 tenaga kerja, Kota Surabaya $17,44 \%$, atau total sebesar 1.051.987 tenaga kerja, Kabupaten Pasuruan 10,53\% atau total sebesar 635.417 tenaga kerja dan Kabupaten Gresik 9,91\% atau total sebesar 597.891 tenaga kerja (lihat gambar 1). 
Apabila dilihat dari gambar 1, maka dapat diketahui bahwa keadaan tingkat jumlah penyerapan tenaga kerja pada industri manufaktur besar dan menengah pada tingkat kabupaten/kota di Jawa Timur menunjukkan adanya fluktuasi ( naik - turun ), penurunan tersebut dapat dilihat dari jumlah tenaga kerja di Jawa Timur yang ditunjukkan pada tahun 2002 - 2004 yakni masing masing sebesar dari 857.456 tenaga kerja menjadi turun sebesar 856.876 tenaga kerja, dan turun lagi menjadi 823.290 tenaga kerja. Sedangkan untuk tahun 2005 - 2008 mengalami peningkatan secara terus menerus dari
832.059 tenaga kerja menjadi 841.520 tenaga kerja dan naik sebesar 895.026 tenaga kerja dan menjadi 916.529 tenaga kerja pada tahun 2008.

Adapun upah tertinggi industri manufaktur besar dan menengah pada tingkat kabupaten/ kota di Jawa Timur tahun 2002 - 2008 yaitu Kabupaten Sidoarjo 19,56 \% atau total sebesar Rp. 9.695.603.902.000, Kota Surabaya 18,99 \% atau total sebesar Rp. 9.441.198.173.000, Kabupaten Gresik 12,88\% atau total sebesar Rp. 6.382.409.399.000 dan Kabupaten Pasuruan 10,06\% atau total sebesar Rp. 4.988.031.279.000 (lihat gambar 2).

\section{Gambar 1. Perkembangan Jumlah Penyerapan Tenaga Kerja Industri Manufaktur Besar dan Menengah di Jawa Timur Tahun 2002 - 2008}

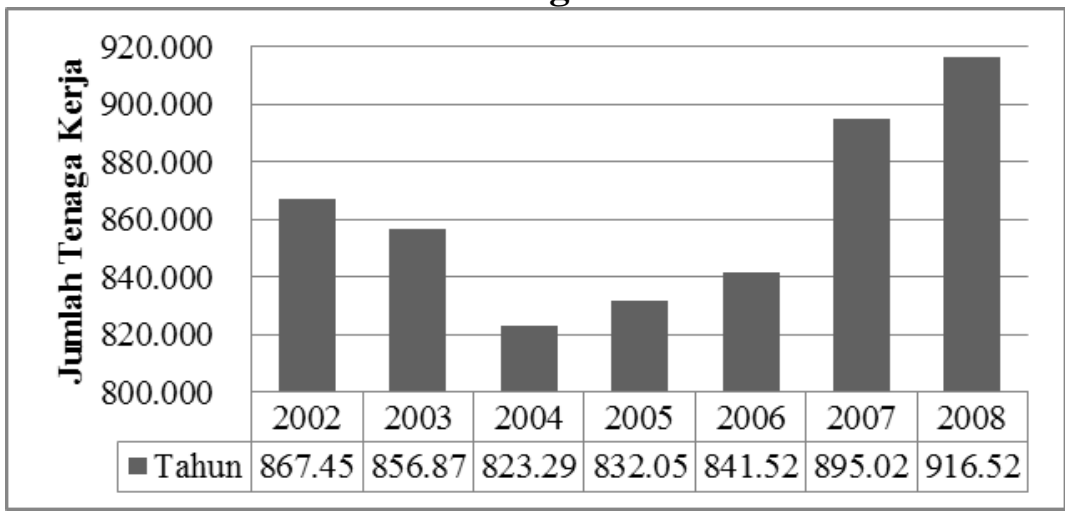

Sumber : BPS Jawa Timur ( data diolah ) 
Gambar 2. Perkembangan Total Upah Industri Manufaktur Besar dan Menengah di Jawa Timur Tahun 2002 - 2008 (Trilyun Rupiah)

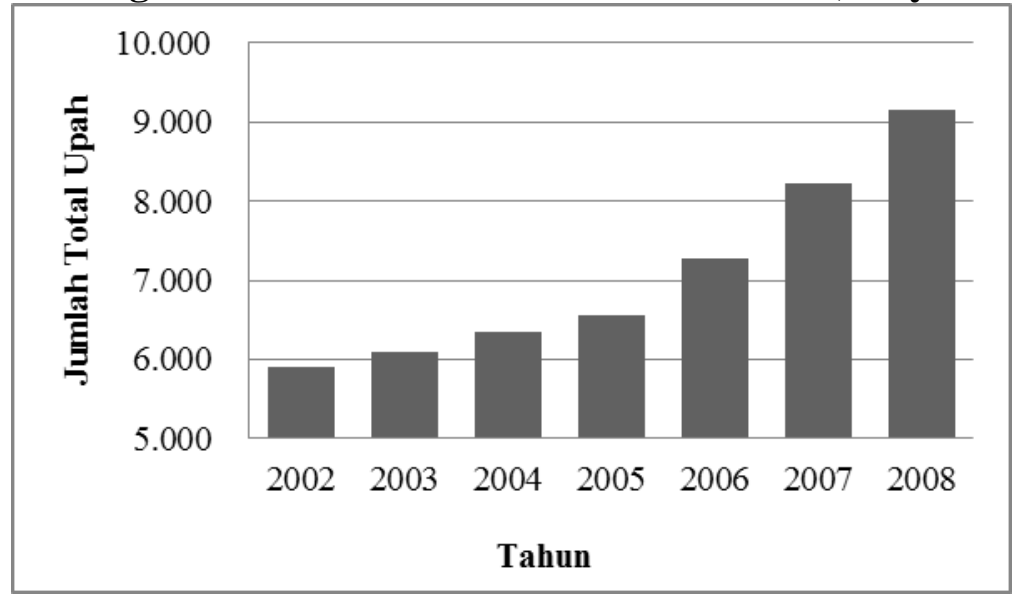

Sumber : BPS Jawa Timur ( data diolah )

\section{Gambar 3. Perkembangan Jumlah Bahan Baku Industri Manufaktur Besar dan Menengah di Jawa Timur Tahun 2002 - 2008 ( Trilyun Rupiah )}

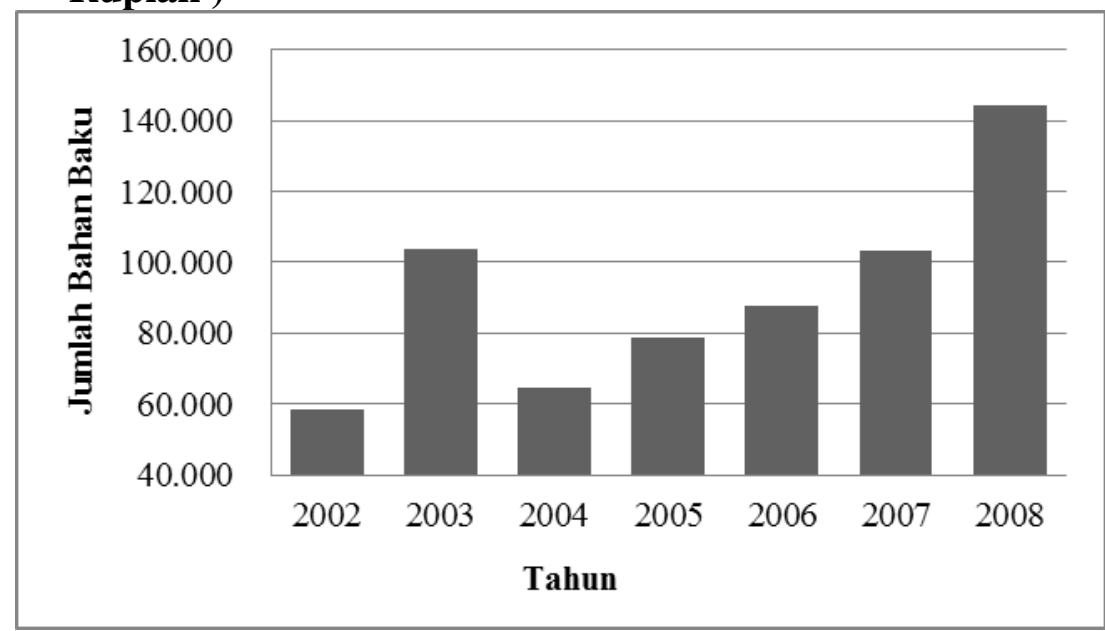

Sumber : BPS Jawa Timur ( data diolah )

Apabila dilihat dari gambar 2, Timur, pada tahun 2002 - 2008 yakni maka dapat diketahui bahwa masing - masing sebesar dari Rp. perkembangan tingkat total upah pada 5.900 Trilyun, menjadi Rp. 6.099 industri manufaktur besar dan Trilyun, meningkat menjadi Rp. menengah pada tingkat 6.348 Trilyun dan meningkat lagi kabupaten/kota di Jawa Timur sebesar Rp. 6.561 Trilyun, menjadi menunjukkan adanya peningkatan Rp. 7.277 Trilyun dan Rp. 8.219 secara terus menerus dari tahun 2002 Trilyun, sehingga menjadi Rp. 9.161 - 2008 . Peningkatan tersebut dapat Trilyun. dilihat dari jumlah total upah di Jawa 
Bahan baku tertinggi pada meningkat menjadi Rp. 144.279 industri manufaktur besar dan Trilyun. menengah pada tingkat kabupaten/ kota di Jawa Timur tahun 2002 2008 yaitu Kabupaten Sidoarjo 24,54 $\%$ atau total sebesar Rp. 157.428.358.701.000, Kota Surabaya $22,69 \%$ atau total sebesar Rp. 145.556.883.162.000, Kabupaten Gresik sebesar $16,22 \%$ atau total sebesar Rp.104.017.566.466.000 dan Kabupaten Pasuruan sebesar 11,57 \% atau total sebesar Rp.74.213.358.411.000 (lihat gambar $3)$.

Apabila dilihat dari gambar 3, maka dapat diketahui bahwa keadaan perkembangan jumlah bahan baku pada industri manufaktur besar dan menengah di Jawa Timur menunjukkan adanya fluktuasi dari tahun 2002 - 2004 yakni masing masing sebesar dari Rp.58.152 Trilyun, meningkat menjadi Rp. 103.821 Trilyun dan mengalami penurunan menjadi Rp. 64.773 Trilyun. Sedangkan pada tahun 2005 meningkat sebesar Rp. 78.765 Trilyun, menjadi Rp. 87.896 Trilyun pada tahun 2006 , meningkat lagi pada tahun 2007 sebesar Rp. 103.365 Trilyun dan pada tahun 2008 pada industri manufaktur besar dan menengah pada tingkat kabupaten/ kota di Jawa Timur tahun 2002 2008 yaitu Kabupaten Sidoarjo 13,98 $\%$ atau total sebesar 4993 perusahaan, Kota Surabaya $13,77 \%$, atau total sebesar 4916 perusahaan, Kabupaten Pasuruan $9,73 \%$ atau total sebesar 3473 perusahaan dan Kabupaten Gresik 8,65\% atau total sebesar 3089 perusahaan (lihat gambar 4).

Apabila dilihat pada gambar 4 , maka dapat diketahui bahwa perkembangan jumlah perusahaan pada industri manufaktur besar dan menengah pada tingkat kabupaten/kota di Jawa Timur menunjukkan fluktuasi dari tahun 2002 - 2005. Sedangkan tahun 2006 - 2007 mengalami peningkatan dari 4.715 perusahaan menjadi 6.257 perusahaan, tetapi pada tahun 2008 jumlah perusahaan mengalami penurunan sebesar 6.245 perusahaan.

Produksi tertinggi pada industri manufaktur besar dan menengah pada tingkat kabupaten/ kota di Jawa Timur tahun 2002 - 2008 yaitu Kabupaten Sidoarjo 20,65 \% atau 
total

sebesar

Kota Kediri sebesar 11,24\% atau

Rp.251.355.552.451.000,

Kota

total sebesar Rp.136.842.393.408.000

Surabaya $22,03 \%$ atau total sebesar dan Kabupaten Pasuruan sebesar

Rp. 268.095.427.070.000, Kabupaten $10,26 \%$ atau total sebesar Rp.

Gresik sebesar 13,64 \% atau total 124.917.185.701.000 (lihat gambar sebesar

Rp.166.032.160.386.000,

5).

Gambar 4. Perkembangan Jumlah Perusahaan Industri Manufaktur Besar dan Menengah di Jawa Timur Tahun 2002 - 2008

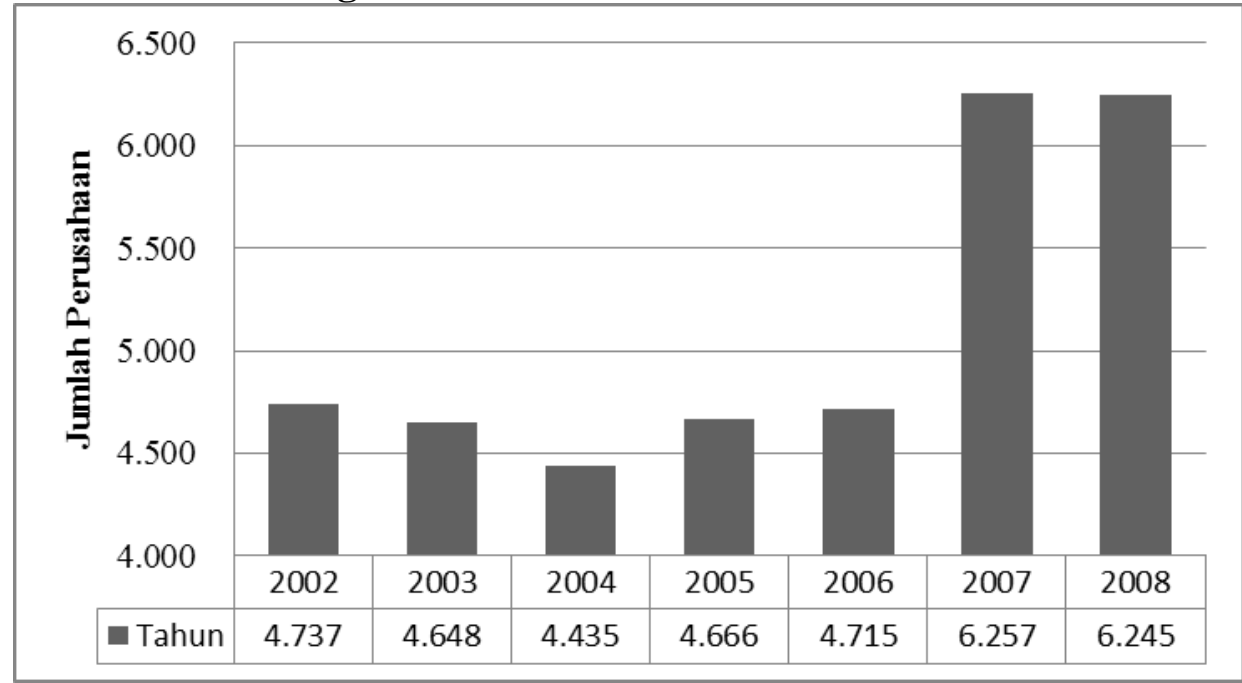

Sumber : BPS Jawa Timur ( data diola

Gambar 5. Perkembangan Jumlah Produksi Industri Manufaktur Besar dan Menengah di Jawa Timur Tahun 2002 - 2008 (Trilyun Rupiah)

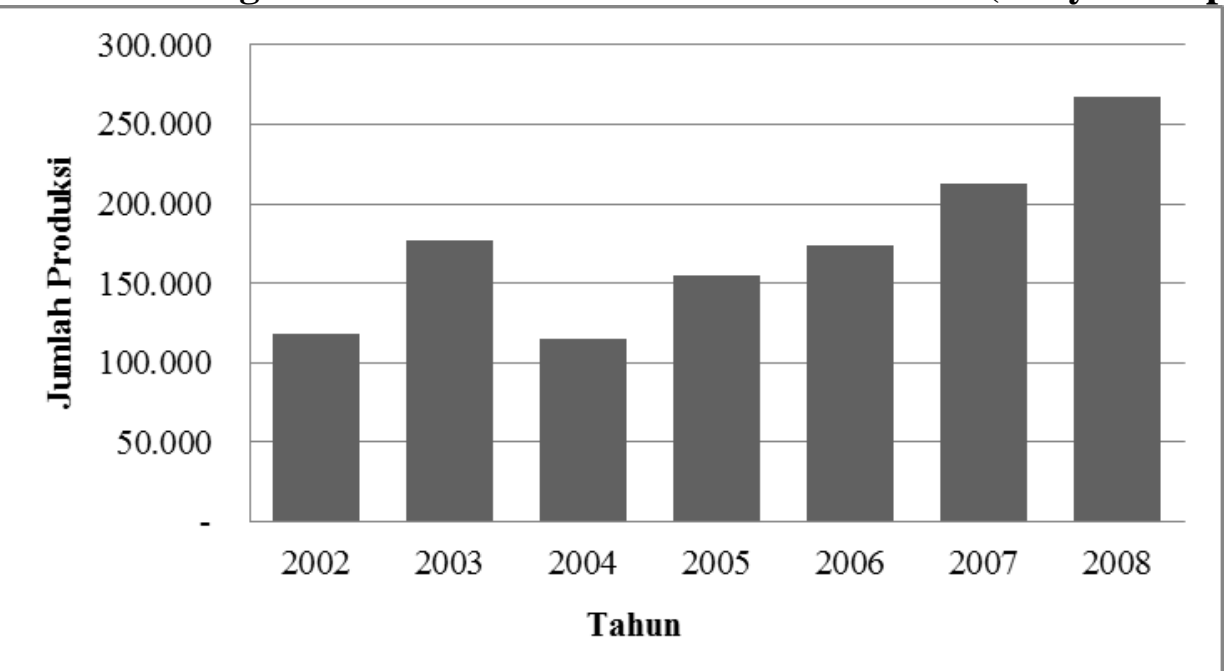

Sumber : BPS Jawa Timur (data diolah) 
Tabel 1. Kontribusi Pengaruh Variabel Bebas terhadap Variabel Terikat

\begin{tabular}{lllrl}
\hline \multicolumn{1}{c}{ Variabel bebas } & \multicolumn{1}{c}{$\begin{array}{c}\text { Koefisien } \\
\text { Regresi }\end{array}$} & $\begin{array}{c}\text { Standart } \\
\text { Error }\end{array}$ & t & Sign t \\
\hline Total Upah ( X1) & 0,383 & 0,41 & 9,333 & 0,000 \\
Bahan baku (X2) & 0,150 & 0,060 & 2,513 & 0,013 \\
Jmlh.Perusahaan ( X3) & 0,156 & 0,043 & 3,626 & 0,000 \\
Produksi ( X4) & 0,118 & 0,057 & 2,088 & 0,038 \\
Constant $=-1,626$ & Adjusted R Square $=0,948$ & \\
Multiple R $=0,974$ & F & $=1199,308$ & \\
R Square & Signifikan F & $=0,000$ & \\
\hline
\end{tabular}
Sumber : BPS Jawa Timur

Gambar 5 menunjukkan perkembangan jumlah produksi industri manufaktur besar dan menengah di Jawa Timur pada tahun 2002 - 2008. Pada tahun 2002 sebesar Rp. 117.623 Trilyun dan mengalami peningkatan pada tahun 2003 sebesar Rp176.491 Trilyun, sedangkan pada tahun 2004 mengalami penurunan produksi sebesar dan pada tahun 2004 mengalami penurunan sebesar Rp. 114.737 Trilyun. Pada tahun 2005 2008 mengalami peningkatan secara terus menerus dari Rp.154.438 Trilyun, menjadi Rp. 173.720 Trilyun dan meningkat lagi sebesar Rp. 213.036 Trilyun, sehingga meningkat menjadi Rp. 266.927 Trilyun.

Data-data tersebut kemudian di analisa dengan analisis regresi berganda, sesuai dengan hasil pengolahan data yang telah dilakukan maka persamaan regresinya adalah $\log Y=\log \beta_{0}+\log \beta_{1} X_{1}+\log \beta_{2}$ $X_{2}+\log \beta_{3} X_{3}+\log \beta_{4} X_{4}+$ e. Dimana : $\mathrm{Y}=$ Penyerapan Tenaga kerja Industri Manufaktur Besar dan Menengah pada Tingkat Kabupaten/Kota di Jawa Timur; X1 = Total Upah Industri Manufaktur Besar dan Menengah pada Tingkat Kabupaten/Kota di Jawa Timur; $\mathrm{X}_{2}=$ Bahan Baku Industri Manufaktur Besar dan Menengah pada Tingkat Kabupaten/Kota di Jawa Timur; $\mathrm{X}_{3}=$ Jumlah Perusahaan Industri Manufaktur Besar dan Menengah pada Tingkat Kabupaten / Kota di Jawa Timur; $\mathrm{X}_{4}=$ Produksi Industri Manufaktur Besar dan Menengah pada Tingkat Kabupaten/Kota di Jawa Timur.

Berdasarkan pada tabel 1 dapat diperoleh persamaan regresi $\mathrm{Y}=$ $1,626+0,383 X_{1}+0,150 X_{2}+0,156$ $\mathrm{X}_{3}+1,118 \mathrm{X}_{4}+$ e. Nilai konstanta $\beta_{0}$ adalah - 1,626 menunjukkan besarnya 
penyerapan tenaga kerja pada industri manufaktur besar dan menengah pada tingkat kabupaten / kota di Jawa Timur apabila tidak ada variabel bebas adalah sebesar $\beta_{0}=-1,260$. Nilai koefisien regresi total upah $\left(\mathrm{X}_{1}\right)$ sebesar 0,383 berarti apabila terjadi peningkatan total upah sebesar $1 \%$ maka akan terjadi peningkatan penyerapan tenaga kerja pada industri manufaktur besar dan menengah pada tingkat kabupaten / kota di Jawa Timur sebesar $0,383 \%$ dengan asumsi bahwa variabel lain yakni $\mathrm{X}_{2}$, $\mathrm{X}_{3}, \mathrm{X}_{4}$ adalah tetap.

Nilai koefisien regresi bahan baku $\left(\mathrm{X}_{2}\right)$ sebesar 0,150 berarti apabila terjadi peningkatan bahan baku sebesar $1 \%$ maka akan terjadi peningkatan penyerapan tenaga kerja pada industri manufaktur besar dan menengah pada tingkat kabupaten / kota di Jawa Timur sebesar 0,150 \% dengan asumsi bahwa variabel lain yakni $\mathrm{X}_{1}, \mathrm{X}_{3}, \mathrm{X}_{4}$ adalah tetap.

Nilai koefisien regresi jumlah perusahaan $\left(\mathrm{X}_{3}\right)$ sebesar 0,156 berarti apabila terjadi peningkatan jumlah perusahaan sebesar $1 \%$ maka akan terjadi peningkatan penyerapan tenaga kerja pada industri manufaktur besar dan menengah pada tingkat kabupaten / kota di Jawa Timur sebesar $0,156 \%$ dengan asumsi bahwa variabel lain yakni $\mathrm{X}_{1}$, $\mathrm{X}_{2}, \mathrm{X}_{4}$ adalah tetap.

Nilai koefisien regresi produksi $\left(\mathrm{X}_{4}\right)$ sebesar 1,118 berarti apabila terjadi peningkatan produksi sebesar $1 \%$ maka akan terjadi peningkatan penyerapan tenaga kerja industri manufaktur besar dan menengah pada tingkat kabupaten / kota di Jawa Timur sebesar 1,118 \% dengan asumsi bahwa variabel lain yakni $\mathrm{X}_{1}$, $\mathrm{X}_{2}, \mathrm{X}_{3}$ adalah tetap.

Setelah diketahui nilai koefisien masing-masing variabel, maka dilakukan uji $\mathrm{t}$ sebagai parameter secara parsial, dengan tingkat signifikan $\alpha=5 \%$. Untuk melihat adaya tidaknya pengaruh dari masing - masing variabel bebas terhadap variabel terikat secara terpisah atau sendiri - sendiri dapat dilihat dengan uji $\mathrm{t}$ ( $\mathrm{t}-$ test ) yaitu dengan membandingkan nilai t hitung dengan t tabel.

Teknik uji t yang dilakukan yaitu dengan melihat nilai t signifikan pada hasil pengolahan data. Dalam penelitian ini $\alpha$ (alfa) yang digunakan yaitu sebesar $5 \%(0,05)$. 
Tabel 2. Hasil Uji t

\begin{tabular}{lcccc}
\hline Variabel & t hitung & t tabel & Sig & Keterangan \\
\hline Total Upah & 9,333 & 1,960 & 0,000 & Signifikan \\
Bahan baku & 2,513 & 1,960 & 0,000 & Signifikan \\
Jumlah perusahaan & 3,626 & 1,960 & 0,000 & Signifikan \\
Produksi & 2,088 & 1,960 & 0,000 & Signifikan \\
\hline
\end{tabular}

Sumber : BPS Jawa Timur

Berdasarkan pada tabel 2 dapat diketahui bahwa untuk masingmasing variabel bebas meliputi total upah $\left(\mathrm{X}_{1}\right)$, bahan baku $\left(\mathrm{X}_{2}\right)$, jumlah perusahaan $\left(\mathrm{X}_{3}\right)$ dan produksi $\left(\mathrm{X}_{4}\right)$ mempunyai nilai t hitung $>\mathrm{t}$ tabel, dengan demikian diputuskan untuk menolak hipotesis nol $\left(\mathrm{H}_{0}\right)$ dan menerima hipotesis alternatif $\left(\mathrm{H}_{\mathrm{a}}\right)$. Secara parsial masing-masing variabel berpengaruh signifikan terhadap penyerapan tenaga kerja (Y) pada industri manufaktur besar dan menengah pada tingkat kabupaten/kota di Jawa Timur.

Setelah hasil uji $t$ sudah diketahui, maka berikuntnya dilakukan uji F yang digunakan untuk mengetahui apakah variabel bebas secara serempak berpengaruh signifikan terhadap variabel tidak bebas atau terikat. Pengujian setiap koefisien regresi bersama-sama dikatakan signifikan bila nilai mutlak $F_{\text {hit }}>F_{\text {tabel }}$ atau nilai probabilitas signifikan lebih kecil dari 0,05 (tingkat kepercayaan yang dipilih) maka hipotesis nol $\left(\mathrm{H}_{0}\right)$ ditolak dan hipotesis alternatif $\left(\mathrm{H}_{\mathrm{a}}\right)$ diterima, sebaliknya dikatakan tidak signifikan bila nilai $F_{\text {hit }}<F_{\text {tabel }}$ atau nilai probabilitas signifikan lebih besar dari 0,05 (tingkat kepercayaan yang dipilih) maka hipotesis nol $\left(\mathrm{H}_{0}\right)$ diterima dan hipotesis alternatif $\left(\mathrm{H}_{\mathrm{a}}\right)$ ditolak.

Teknik uji $\mathrm{F}$ yang dilakukan yaitu dengan melihat nilai $F$ signifikan pada hasil pengolahan data, diiketahui bahwa $F_{\text {hit }}$ sebesar 1199,308 dan $F_{\text {tabel }}$ sebesar 2,37 sehingga menunjukkan bahwa $\mathrm{F}_{\text {hit }}>$ $F_{\text {tabel }}$ atau nilai probabilitas signifikan lebih kecil dari 0,05 (tingkat kepercayaan yang dipilih) maka keputusannya adalah menolak hipotesis nol $\left(\mathrm{H}_{0}\right)$ dan menerima hipotesis alternatif $\left(\mathrm{H}_{\mathrm{a}}\right)$.

Sehingga dapat disimpulkan bahwa ada pengaruh secara serentak 
atau bersama-sama dari semua variabel bebas meliputi : total upah $\left(\mathrm{X}_{1}\right)$, bahan baku $\left(\mathrm{X}_{2}\right)$, jumlah perusahaan $\left(\mathrm{X}_{3}\right)$ dan produksi $\left(\mathrm{X}_{4}\right)$ terhadap variabel terikat atau penyerapan tenaga kerja (Y) pada industri manufaktur besar dan menengah pada tingkat kabupaten / kota di Jawa Timur.

Langkah berikutnya yaitu dengan menganalisis koefisien determinasi regresi, berdasarkan hasil perhitungan diperoleh besarnya koefisien determinasi $\left(\mathrm{R}^{2}\right)$ sebesar 0,948 atau sebesar $94,8 \%$ yang berarti variabel bebas meliputi total upah, bahan baku, jumlah perusahaan dan produksi berpengaruh sebesar $94,8 \%$ terhadap penyerapan tenaga kerja pada industri manufaktur besar dan menengah pada tingkat kabupaten / kota di Jawa Timur. Sedangkan sisanya sebesar $5,2 \%$ di pengaruhi oleh variabel lain yang tidak di ikutkan dalam penelitian ini. Prosentase pengaruh variabel independent terhadap variabel dependent dalam persamaan regresi tersebut menunjukkan pengaruh yang besar yaitu 94,8\% dengan demikian jika diukur dari besarnya pengaruh total upah, bahan baku, jumlah perusahaan dan produksi terhadap penyerapan tenaga kerja pada industri manufaktur besar dan menengah pada tingkat kabupaten / kota di Jawa Timur. Dari hasil analisa secara keseluruhan dapat disimpulkan bahwa secara bersama-sama menunjukkan variabel bebas meliputi total upah, bahan baku, jumlah perusahaan dan produksi berpengaruh terhadap variabel terikat yakni tenaga kerja pada industri manufaktur besar dan menengah pada tingkat kabupaten / kota di Jawa Timur.

\section{PENUTUP}

Total upah, bahan baku, jumlah perusahaan dan produksi berpengaruh secara signifikan terhadap penyerapan tenga kerja pada industri manufaktur besar dan menengah pada tingkat kabupaten/kota di Jawa Timur. Hal ini dapat dilihat dari hasil analisa regresi yang menyebutkan bahwa total upah sebesar 0,383 , bahan baku sebesar 0,150, jumlah perusahaan sebesar 0,156 dan produksi sebesar 1,118. Sehingga berdasarkan hasil analisa regresi tersebut menunjukkan adanya pengaruh yang signifikan antara variabel bebas $\left(\mathrm{X}_{1}, \mathrm{X}_{2}, \mathrm{X}_{3}, \mathrm{X}_{4}\right)$ terhadap penyerapan tenaga kerja $(\mathrm{Y})$ 
pada industri manufaktur besar dan menengah pada tingkat kabupaten/kota di Jawa Timur tahun 2002 - 2008. Dari hasil perhitungan koefisien determinasi $\left(\mathrm{R}^{2}\right)$ sebesar 0,948 atau sebesar $94,8 \%$ yang berarti variabel bebas meliputi total upah, bahan baku, jumlah perusahaan dan produksi berpengaruh sebesar $94,8 \%$ terhadap penyerapan tenaga kerja Industri Manufaktur Besar dan Menengah pada Tingkat Kabupaten / Kota di Jawa Timur Tahun 2002 2008, sedangkan sisanya sebesar $5,2 \%$ di pengaruhi oleh variabel lain yang tidak di ikutkan dalam penelitian ini.

\section{DAFTAR PUSTAKA}

Arsyad, Lincolin. 1993. Metodologi Penelitian Ekonomi dan Bisnis. Edisi revissi UPP AMP YKPN : Yogyakarta.

Basu dan Ibnu Sukotjo, Swasttha. 1997. Penagntar Bisnis Modern. BEFE : Yogyakarta.

Bangun Sektor Industri 2025 (online) (http // www.scibid.com, diakses 5 Mei 2011).

BPS. Pertumbuhan Produksi Industri Manufaktur (online) (http// jatim.bps.go.id, diakses 1 Maret 2011).

Habiba, Herlin farda. 2007. Faktor Faktor yang Mempengaruhi Penyerapan Tenaga Kerja
Pada Industri Manufaktur di Jawa Timur tahun 1995 2004. Skripsi.Malang. FE. UMM.

Haryanto, Ade. 2004. Analisa Faktor - Faktor yang Mempengaruhi Jumlah Penyerapan Tenaga Kerja Industri Manufaktur di Jawa Barat tahun 1990- 1999. Skripsi. Malang. FE. UMM.

Jurnal Ekonomi Pembangunan, Disparitas Dan Pola Spesialisasi Tenaga Kerja Industri Regional 1993 - 1996 danan Prospek Pelaksanaan Otonomi (online) (http// www.google.com, diakses 6 Mei 2011)

Mantra, Ida Bagoes. 2006. Demografi Umum. Edisi kedua. Penerbit Pustaka Belajar Yogyakarta.

Matz. 1990. Akuntansi Biaya: Perencanaan dan Pengendalian. Jakarta: Erlangga.

Simanjuntak, P.J. 1985. Pengantar Ekonomi Sumber Daya Manusia. Penerbit Fakultas Ekonomi Universitas Indonesia.

Sukirno, Sadono.2009. Mikroekonomi Teori Pengantar. Edisi ketiga. Penerbit PT Rajagrafindo Persada : Jakarta.

Sumarsono, Sony. 2003. Ekonomi Manajemen Sumber Daya Manusia dan Ketenagakerjaan. Yogyakarta: Graha Ilmu. 
Suparmoko. 1993. Pengantar Zainal, arifin. 2002. Konsentrasi Ekonomika Mikro. Spasial dan Dinamika Yogyakarta: BPFE Pertumbuhan Industri Manufaktur di Jawa Timur. Laporan Penelitian. 